\section{Innovations for potential entrepreneurs in service quality and customer loyalty in the hospitality industry}

\author{
Zoya Wajid Satti
}

Department of Management Sciences, COMSATS University Islamabad, Attock Campus, Islamabad, Pakistan

Samreen Fahim Babar Department of Management Sciences, Bahria University, Islamabad, Pakistan

Shagufta Parveen

Department of Management Sciences, COMSATS University Islamabad, Attock Campus, Islamabad, Pakistan

Kashif Abrar

Department of Management Sciences, Bahria University, Islamabad, Pakistan, and

Asma Shabbir

Department of Management Sciences, COMSA TS University Islamabad, Attock Campus, Islamabad, Pakistan
Potential entrepreneurs in service quality

Received 26 August 2019 Revised 26 December 2019

15 January 2020

27 February 2020

15 April 2020

31 May 2020

12 June 2020

27 August 2020

Accepted 5 September 2020

\begin{abstract}
Purpose - This study aims to investigate the role of moderated mediation between innovation in service quality and customer loyalty in the hospitality industry for potential entrepreneurs in the hospitality industry. Design/methodology/approach - The authors have collected data from customers of the hospitality industry of significant cities of Pakistan using 362 structured questionnaires. Structural equation modelling was used to find out moderated mediation between innovation in service quality and customer loyalty in the hospitality industry for potential entrepreneurs in the hospitality industry.

Findings - The results showed that the role of customer satisfaction as a mediator and the role of perceived price fairness as a moderator between service quality and customer loyalty is statistically significant. Customers are influenced by price, and it leads to their satisfaction in the hospitality industry.

Research limitations/implications - The results of this study can be used by managers of the restaurant industry to enhance customer loyalty by focusing on customer satisfaction and perceived price.
\end{abstract}

(C) Zoya Wajid Satti, Samreen Fahim Babar, Shagufta Parveen, Kashif Abrar and Asma Shabbir. Published in Asia Pacific Journal of Innovation and Entrepreneurship. Published by Emerald Publishing Limited. This article is published under the Creative Commons Attribution (CC BY 4.0) licence. Anyone may reproduce, distribute, translate and create derivative works of this article (for both commercial and non-commercial purposes), subject to full attribution to the original publication and authors. The full terms of this licence maybe seen at http://creativecommons.org/licences/by/4.0/ legalcode

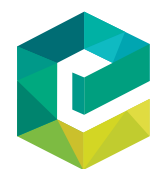

Asia Pacific Journal of Innovation and Entrepreneurship Vol. 14 No. 3, 2020 pp. $317-328$

Emerald Publishing Limited e-ISSN: $2398-7812$ p-ISSN: 2071-1395 DOI 10.1108/APJE-08-2019-0063 
APJIE 14,3

Originality/value - The evidence documented in this paper is first known to measure the role of a mediator and moderator between service quality and customer loyalty for potential entrepreneurs. This paper will add to the literature of service quality in the hospitality industry concerning the role of customer satisfaction and perceived price fairness for future and potential entrepreneurs.

Keywords Innovations, Service quality, Customer satisfaction, Perceived price, Customer loyalty, Innovation, Entrepreneurs

Paper type Research paper

\section{Introduction}

The restaurant industry is facing massive change because of factors like changes in the lifestyle of customers, their perceptions, education level and awareness because of social media. Current consumers require a quick and timely response and customised services according to their requirements (Ivkov et al., 2018). Entrepreneurs have played a vital role in influencing all the industries and different segments of society as they focus on innovations, productivity, profit maximisation and employment generation (Li and Asim, 2019). Opportunities for starting one's restaurant in Pakistan are very lucrative for entrepreneurs. Pakistanis spend $40 \%$ of their income on dining out and on readymade food outside their home. They spend almost 114.78 billion on eating out annually (Shaikh and Zahid, 2018). There are some critical factors that current and potential entrepreneurs must keep in mind if they want to maximise their profits and increase their number of customers. These factors include service quality, perceived price and satisfaction of customers. Restaurants can bring innovation to current products and services or can introduce a new product or service altogether. For example, the atmosphere of the restaurant can have a positive and negative affect on the perception of the customers and the vision of restaurant. Dining out is more than just going to a restaurant to eat (Satti et al., 2017).

The restaurants' managers are now focusing on innovative methods to attract customers. They have to keep in mind the perceived price of the customer when introducing any new product and service (Matzler et al., 2006). Perceived price is based upon the subjective judgement of the customer about the benefits of a service and product along with the comparison with the competitors' price, which they take as a reference (Han and Hyun, 2015). So, marketing managers must match the cost of new products or services to the perception of their customers and the quality they are going to provide. If customers found the product or service overpriced than their perceived price, then they might switch to other brands offering the same features (Ivkov et al., 2018). Service quality, customer satisfaction and perceived price are essential factors that lead to customer loyalty (Cha and Borchgrevink, 2018; Satti et al.,2019).

The primary focus of the current study is to investigate the role of customer satisfaction as a mediator and perceived price as a moderator between service quality and customer loyalty in the restaurant industry. Few studies have been conducted in Pakistan, with customer satisfaction as a mediator, but it is done in the financial and telecom industry. The available studies have only examined the relationship of service quality with customer satisfaction and customer loyalty (Khan and Fasih, 2014). Perceived price is not tested as a moderator between service quality and customer loyalty in the restaurant industry to the limited knowledge of authors after reviewing the marketing literature. The present study has tried to fill this gap concerning developing countries and Pakistan, as price determines future consumption.

Perceived price, service quality and customer satisfaction are imperative to consider, as these all lead to customer loyalty. Current entrepreneurs in the restaurant business and their 
marketing managers can also take guidance from the results of the present study to formulate their strategies to retain and attract customers. The restaurant industry of Pakistan has a significant importance in the service sector. Restaurants employ $1.31 \%$ of the total population of Pakistan. The financial survey of Pakistan (2011-2012) indicates the urban populace of Pakistan is 67.55 million, demonstrating a significant business sector for restaurants (Azim et al., 2014). There is growing popularity of "dining out". Regularly, more than 11 million people dine out (Khan and Shaikh, 2011). Family unit visits typically to restaurants and hotels, and their food consumption is 1.14\% (Hussain and Routray, 2012).

The present study is conducted in the restaurant industry, as we can find the presence of all variables there. The significance of these variables can be better calculated from the restaurant industry as the industry interacts with different types of customers daily. There is a progressive change amid the past 1.5 decades in the restaurant business of Pakistan, and the advertisers are using the concept of service quality at a bigger scale (Hussain and Routray, 2012). The purpose of this study is to guide the current and future entrepreneurs in the restaurant industry, which is also the novelty of this research work. This study will guide future entrepreneurs of the restaurant industry as to what factors are essential to keep in mind while focusing on innovations.

\section{Literature review and hypothesis development}

\section{Service quality and customer satisfaction}

There is intense competition in the restaurant industry, so owners must focus on innovative ideas to attract new customers and to retain current customers. Innovation helps in improving existing products and services (Ouedraogo and Koffi, 2018) and creates satisfaction among customers. It also helps in the introduction of new services and products to attract new customers and retain existing customers.

According to Mustafa (2019), service innovations can bring new customers and help in satisfying current customers. Service innovations have become more important than product-based innovations, as a competitor can easily copy product base innovations after some time. Innovations can be brought through entrepreneurship, especially "indigenous entrepreneurship", which plays a vital role in developing the international economy by enhancing technology building skills, dissemination of innovation and mobilising the capital. Service quality is an essential predecessor of customer satisfaction (Dahiyat et al., 2011). It is believed that a company can generate success if it provides superior value to its customers than its competitors, which is only possible by lowering prices, offering excellent quality and personalisation (Kiani et al., 2019). The existence of a business depends on the skills of its entrepreneur, who can help it create a competitive edge in the industry (Hutahayan, 2019). So, providing excellent quality services can lead to better customer satisfaction. Based on this discussion, the first hypothesis of the current study is developed:

H1. There is a positive relationship between service quality and customer satisfaction.

\section{Service quality, customer satisfaction and customer loyalty}

Loyalty is all about satisfying the right customers to whom you can provide the best quality services so that they come back to avail services (Boshoff, 2007). Customer satisfaction leads to customer loyalty. The chances of customers to revisit or purchase the same product increase if they are satisfied, and they recommend it to the others with a positive word of mouth (Wolfinbarger and Gilly, 2003). The causal connection among service quality and customer satisfaction has an immediate effect on customer loyalty has been discussed in the 
literature (Nauman et al., 2010). So, based on this discussion, the second and third hypotheses of the present study are developed:

H2. There is a positive relationship between service quality and customer loyalty.

H3. There is a positive relationship between customer satisfaction and customer loyalty.

Customer satisfaction as a mediator and perceived price fairness as moderator

Consumer behaviour can be explained significantly by the price of the product and service (Keaveney, 1995). Perceived price is defined as "the customer's judgment about a service's average price in comparison to its competitors" (Chen et al., 1994). According to this approach, the customer compares the pricing with the competitors, whether they are charged more, less or equal to them. Customer perception plays a vital role in building their attitude towards service, as price is highly associated with value; customers evaluate the service value and pay for it accordingly (Zeithaml, 1988). Value perception measurement includes perceived price in the marketing literature. Although customer satisfaction is moderately affected by value, few studies have investigated the moderating effect of perceived price in association between service quality and customer satisfaction in the restaurant industry (Caruana et al., 2000). Precisely, when customers' perceived price is in accordance with the quality of food provided, they will be more satisfied with the restaurant (Ryu and Han, 2010). In addition to service quality and perceived price interaction, customer satisfaction is more likely to increase, resulting in high customer loyalty. So, based on this discussion, the fourth and fifth hypotheses of the current study are developed:

H4. Customer satisfaction partially mediates the positive relationship between service quality and customer loyalty.

H5: Perceived price fairness moderates the mediation between service quality and customer loyalty.

From the above theoretical link mentioned literature, we can say that to satisfy the current customers, to retain them in the long run and to attract new customers, current and potential entrepreneurs in the restaurant industry must focus on bringing innovations in service quality by keeping in mind perceived price. Service quality and perceived price both influence customer satisfaction and customer loyalty. We have formulated the following theoretical model (Figure 1).

\section{Methodology}

A modified questionnaire was used to collect the data from the customers. The sample size was 362 customers availing services of different restaurants of major cities, including Islamabad, Rawalpindi, Lahore, Peshawar, Quetta and Karachi. These questionnaires were sent to them by email and post. The purpose of this study was communicated to them before obtaining their consent for completing the questionnaires. Consent of customers was taken after, and questionnaires were posted to them to their respective addresses. The data is collected directly from customers and analysed accordingly.

The restaurants of major cities were taken as the population for the study. Fast-food chains, hotels and roadside food stalls were excluded from this study. The total number of questionnaires were 450 and were equally divided among all major cities, i.e. 75 questionnaires each. The target population for this study were customers earning 


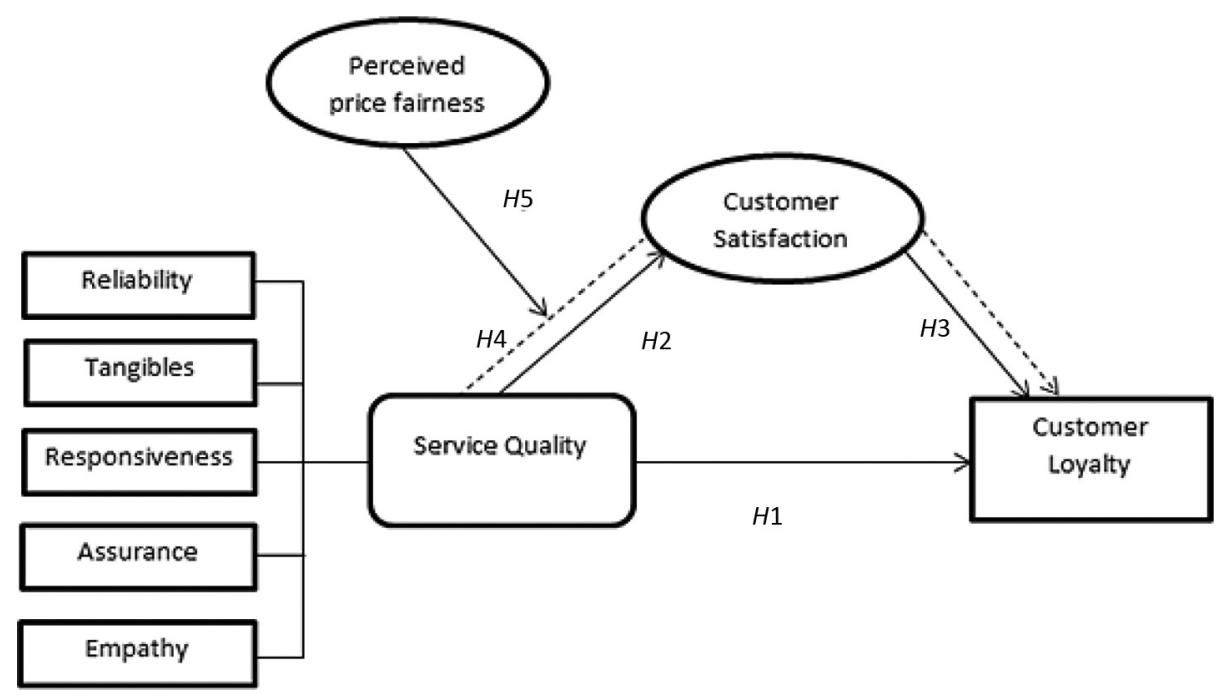

\section{Potential entrepreneurs in service quality}

321

PKR25,000 and above per month. The minimum age of the customer was 25 years and above. Customers were asked about their visits per month, i.e. from once a month to above four times in a month. The sample is divided based on the income of customers. SmartPLS 3.0 was used to analyse the data and role of mediation and moderation between service quality and customer satisfaction.

\section{Measurement of variables}

The variables of the current study are four: service quality, customer satisfaction, perceived price fairness and customer loyalty. The operational definitions of the main variables and their dimensions are given below.

Service quality is defined as the difference between what is expected and what is actually received by the customer in terms of quality of service (Gefen, 2002). Tangibles includes physical facilities, the appearance of personnel, tools or equipment used to provide the service and the physical representation of the service in the restaurants (Parasuraman et al., 1985). Assurance explains the knowledge and ability of employees to deliver trust and confidence to the customers (Parasuraman et al., 1988). Empathy is caring attitude and individual attention given to customers by the service staff (Parasuraman et al., 1988). Reliability explains the consistency of performance and dependability in performing the service at the designated time by the service staff (Parasuraman et al., 1985). Responsiveness involves the willingness of employees to provide prompt services to the customers (Parasuraman et al., 1985). Customer satisfaction is defined as assessing and determining how happy customers are with the company's products, services and competencies (Kotler et al., 2000). Customer loyalty is the extent of a customer's likeliness to do repeat business and purchase a company's product or service (Hallowell, 1996). Perceived price fairness is defined as the judgement of a customer about a service's average price in comparison to its competitors (Chen et al., 1994).

In the first step, a PLS algorithm was run to test the measurement model to test its validity and reliability. In the second step, the structural model was tested by applying the bootstrapping method. The significance of hypotheses and moderated mediation was 
APJIE 14,3

\section{2}

determined by this method. The initial part of this study is based on the demographic characteristics of the respondents, and in the next part, the structural model of the study is discussed in detail.

\section{Demographics analysis}

The respondents were requested to give answers about their gender, age, education, monthly income, number of visits and marital status. The number of visits does affect customer satisfaction and loyalty towards any place or product. The number of visits is significant to calculate because it can give us differentiation in opinions and views about the sensory marketing. Table 1 shows the summary of demographics of the respondents of the present study.

After getting the demographics of respondents of the study, the measurement model was calculated to find out the reliability and validity of our model.

\section{Measurement model}

It is essential to calculate the reliability and validity of research if we want its data to be of value and use. For establishing validity, we have used discriminant validity. For construct reliability, we have used Cronbach $\alpha$ and values of composite reliability. Its value should be greater than 0.70 to establish the reliability and internal consistency of a scale (Fornell and Larcker, 1981). The value of 0.50 or low is acceptable for preliminary construct development (Nunnally, 1967). In our case, composite reliability is also established as all values of all items of instruments are more significant than 0.70. This indicates that this instrument is highly reliable and can be used in any setting to measure the same concept at different points of time. For convergent validity, we examine the average variance extracted (AVE).

\begin{tabular}{llrr}
\hline Group & & & \\
\hline Gender & Items & No. & \% of total \\
\multirow{2}{*}{ Age } & Male & 201 & 55.5 \\
& Female & 161 & 44.5 \\
& 25 years & 30 & 16.3 \\
& $26-30$ years & 65 & 18 \\
& $31-35$ years & 54 & 14.9 \\
& 36-40 years & 67 & 18.5 \\
Education & 41-50 years & 56 & 15.5 \\
& More than 50 years & 61 & 16.9 \\
& High school & 45 & 12.4 \\
Marital status & Graduate & 127 & 35.1 \\
Income (PKR) & Post-graduate & 117 & 32.3 \\
& Higher & 73 & 20.2 \\
& Married & 154 & 42.5 \\
& Single & 208 & 57.5 \\
& 25,000 & 25 & 6.9 \\
& 26,000-35,000 & 75 & 20.7 \\
Total visits & 36,000-45,000 & 55 & 15.2 \\
& 46,000-55,000 & 61 & 16.9 \\
& 56,000-65,000 & 69 & 19.1 \\
& Above 65,000 & 77 & 21.3 \\
& Once in a month & 85 & 23.5 \\
& Twice a month & 92 & 25.4 \\
& Thrice a month & 93 & 25.7 \\
& Above four times & 92 & 25.4 \\
\hline
\end{tabular}

Table 1.

Respondents' demographics 
The values of AVE should be greater than 0.50 , which shows that $50 \%$ or more variance can be accounted for these indicators (Hair et al., 2011). In our case, AVE for all latent variables is greater than 0.70 . Researchers can use it with confidence and can rely on their responses and results. Table 2 shows the construct reliability and convergent validity values for the present study.

Discriminant validity shows that one construct differs from the other construct. According to Fornell and Larcker (1981), AVE should be greater than the variance between the construct and other constructs. We have shown the discriminant validity analysis in Table 3. After establishing the discriminant validity and reliability of the theoretical model, the structural model was tested to know the significance of the hypotheses of the present study.

\section{Structural model assessment}

The structural model assessment helps to find out the relationship between latent and observed variables and their constructs. It also helps to give the contribution of each dimension to the unobserved variable. It is used to find out the direct and indirect effects of variables on each other. We have calculated the total effect, indirect effect and their significance by using path coefficients.

Table 4 shows the relationship between service quality and customer loyalty. We have a path coefficient of $27.6 \%$, and its t-value is greater than 1.96 at $p \leq 0.05$ level of significance. This demonstrates that improved service quality can influence customer loyalty and can increase the net worth of the organisation. The path coefficient of service quality and customer satisfaction shows a $7.7 \%$ value, and its $t$-value higher than 1.96 at $p \leq 0.05$. This shows that including quality in services will make customers happy and satisfied with the products and services of the organisation. Customer satisfaction affects customer loyalty and it is visible from the results as customer satisfaction contributes $14.9 \%$ in generating loyalty in customers. The path coefficient of customer satisfaction towards customer loyalty is significant at a $p$-value of less than $5 \%$. Perceived price has shown a strong effect on creating satisfaction among customers of the hospitality industry in Pakistan, as it is $85.6 \%$, with a $t$-value higher than 1.96 at $p \leq 0.05$. So decisions of customers to revisit and use of

\begin{tabular}{lccc}
\hline & Cronbach's $\alpha$ & Composite reliability & AVE \\
\hline CS & 0.680 & 0.776 & 0.769 \\
PP & 0.702 & 0.812 & 0.846 \\
SQ & 0.925 & 0.926 & 0.830
\end{tabular}

Notes: $\mathrm{CS}=$ Customer satisfaction; $\mathrm{PP}=$ Perceived price; $\mathrm{SQ}=$ Service quality

Table 2.

Construct reliability and convergent validity

\begin{tabular}{|c|c|c|c|c|c|}
\hline & $\mathrm{CL}$ & CS & PP & SQ & \\
\hline $\begin{array}{l}{ }^{*} \mathrm{CL} \\
\mathrm{CS} \\
\mathrm{PP} \\
\mathrm{SQ}\end{array}$ & $\begin{array}{l}0.589 \\
0.060 \\
0.057 \\
0.157\end{array}$ & $\begin{array}{l}0.690 \\
0.361 \\
0.180\end{array}$ & $\begin{array}{l}0.630 \\
0.274\end{array}$ & 0.456 & \\
\hline \multicolumn{5}{|c|}{ Note: ${ }^{*} C L=$ Customer loyalty } & Discriminant validity \\
\hline
\end{tabular}


APJIE 14,3

product and service are affected by the price they perceive as fair. The role of customer satisfaction as a mediator in the theoretical model has proven statistically significant at $5 \%$ level of significance. The path coefficient is $7.9 \%$, with a $t$-value greater than 1.96 . It shows that customer satisfaction plays a vital role as a mediator between service quality and customer loyalty. The role of perceived price as moderator is positive as well as statistically significant at $p \leq 0.05$. This proves the importance of perceived price as a moderator in the model. Table 4 shows the results of the theoretical model for moderated mediation.

\section{Discussion}

All results are showing that improved service quality can bring you potential new customers and increase the loyalty of current customers. An organisation that provides high service quality surpasses the expectations of its customers and increases its profits from increased sales. We can conclude that by providing service quality to the customers of the business, the manager can influence the customer satisfaction level. In turn, customer satisfaction will help to create customer loyalty among your customers and will make them stay with the business in the long run. Focusing on the perceived price by customers will also have a strong impact on creating satisfaction and loyalty among customers of the business. A summary of the hypotheses is given in Table 5 .

Theoretical links of the current study prove the role of customer satisfaction as a mediator and perceived price as a moderator between service quality and customer loyalty. The relationship between service quality and customer satisfaction has been proved positive and significant in the studies conducted by Hussain et al. (2015), Oh and Kim (2017), Kaura et al. (2015), Paek and Lee (2018). The relationship between service quality and customer loyalty has been found significant by Izogo and Ogba (2015), Jiang et al. (2016) and Budianto (2019). The role of customer satisfaction in generating customer loyalty has been proved significant in studies conducted by Schirmer et al. (2018), Bowen and McCain (2015) and Amin (2016). The role of customer satisfaction as a mediator has been proved significant by Kaura et al. (2015), Tandon et al. (2017) and Caruana et al. (2018). The role of perceived price as moderator was explored and found significant by Chang and Wong (2018) and Aqueveque (2015). Figure 2 shows the results for the theoretical model of the present study.

\section{Table 4.}

Moderated mediation

\begin{tabular}{lccrr}
\hline & Path coefficients & SD & T & $P$ \\
\hline $\mathrm{SQ} \rightarrow$ CL & 0.276 & 0.063 & 4.415 & 0.000 \\
$\mathrm{SQ} \rightarrow$ CS & 0.077 & 0.036 & 2.154 & 0.031 \\
$\mathrm{CS} \rightarrow \mathrm{CL}$ & 0.149 & 0.065 & 2.290 & 0.022 \\
$\mathrm{PP} \rightarrow \mathrm{CS}$ & 0.856 & 0.047 & 18.319 & 0.000 \\
$\mathrm{SQ} \rightarrow \mathrm{CS} \rightarrow \mathrm{CL}$ & 0.036 & 2.210 & 0.027 \\
Moderated mediation $\rightarrow$ CS & 0.079 & 0.014 & 2.223 & 0.026 \\
\hline
\end{tabular}

\begin{tabular}{lll}
\hline & Hypothesis & Result \\
\hline H1 & Relationship between service quality and customer satisfaction & Significant \\
H2 & Relationship between service quality and customer loyalty & Significant \\
H3 & Relationship between customer satisfaction and customer loyalty & Significant \\
H4 & Customer satisfaction partially between service quality and customer loyalty & Significant \\
H5 & Perceived price moderately mediates between service quality and customer loyalty & Significant \\
\hline
\end{tabular}




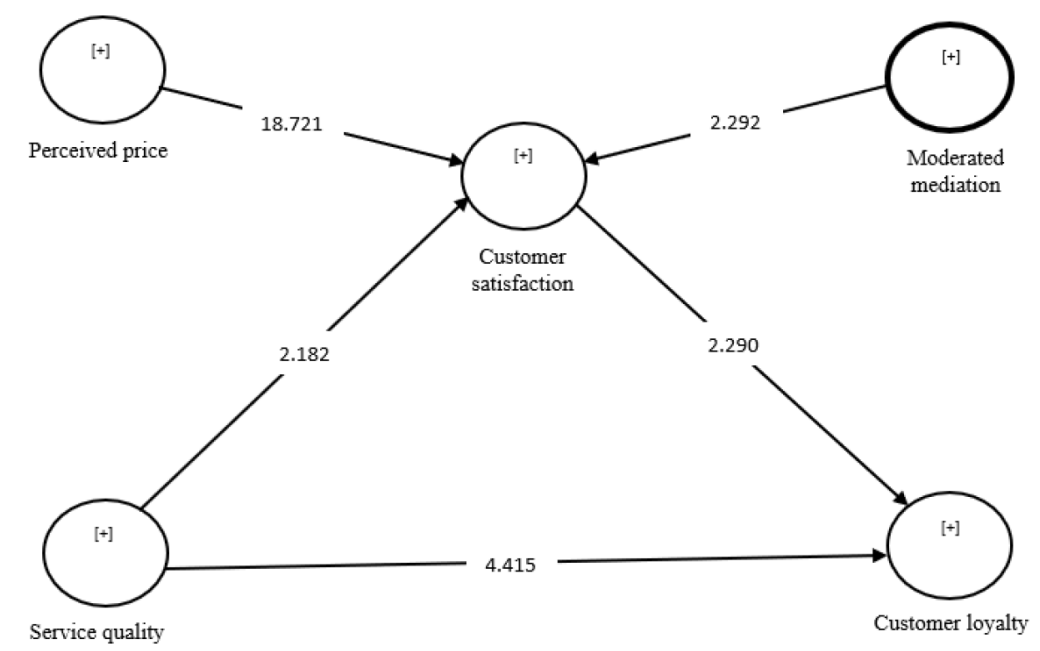

\section{Potential entrepreneurs in service quality}

325

Figure 2.

Moderated mediation between service quality and customer loyalty

After studying the theoretical model, it is evident that perceived price plays a vital role in creating satisfaction and loyalty among customers in the hospitality industry of Pakistan. The hospitality industry should maintain service quality and meet customers' expectations to gain competitive advantage by introducing different and unique ways to entertain their customers. To remain in the competition, managers of the hospitality industry in emerging markets like Pakistan should focus on perceived price and customer satisfaction with service quality to retain customers in the longer run. They must focus on innovations in current and future services and products. Service quality has a positive and significant impact on customer satisfaction, which leads to customer loyalty (Hafeez and Muhammad, 2012). Different marketing programmes can be used to enhance customer loyalty and to satisfy them by providing them quality and low-cost products.

\section{Conclusion}

The primary focus of the current study is to investigate the role of customer satisfaction as a mediator and perceived price as a moderator between service quality and customer loyalty in the restaurant industry. The results of the study have proved the role of customer satisfaction as a mediator and perceived price as a moderator between service quality and customer loyalty in the hospitality industry of Pakistan. This study will guide future entrepreneurs of the restaurant industry as to what factors are essential to keep in mind while focusing on innovations. The evidence and results of the present study can serve as guidance for current and potential entrepreneurs in the restaurant industry to have a successful and profitable business. Marketing managers must keep the price of new products or services according to the perception of their customers and the quality they are going to provide to their customers. If customers found the product or service overpriced than their perceived price, then they might switch to other brands offering the same features. Managers of the hospitality industry in another developing country can take guidance from this study to create satisfied customers by providing them quality and differentiated products and services. Restaurants can bring innovations in current products and services or can introduce a new product or service altogether. The role of perceived price as a moderator will also provide new insights to managers to formulate pricing strategies. 
The results of the present study show that if the hospitality industry offers standardised service quality, then its customers are ready to pay the price for the services and will be satisfied. Customers spend more if they get desired services with quality, and they remain loyal to the restaurant. This study can be used to make province-wide comparisons in the future. More service industries can be targeted in the future to see the relationship between these three variables. This study can be extended to other developing countries for getting more reliable and generalised results. Comparisons can also be drawn between the Asian restaurants' industries.

\section{References}

Amin, M. (2016), "Internet banking service quality and its implication on e-customer satisfaction and e-customer loyalty", International Journal of Bank Marketing, Vol. 34 No. 3, pp. 280-306.

Aqueveque, C. (2015), "The influence of experts' positive word-of-mouth on a wine's perceived quality and value: the moderator role of consumers' expertise", Journal of Wine Research, Vol. 26 No. 3, pp. 181-191.

Azim, A., Shah, N.A., Mehmood, Z., Mehmood, S. and Bagram, M.M.M. (2014), "Factors effecting the customers selection of restaurants in Pakistan", International Review of Management and Business Research, Vol. 3 No. 2, p. 1003.

Boshoff, C. (2007), "A psychometric assessment of ES-QUAL: a scale to measure electronic service quality", Journal of Electronic Commerce Research, Vol. 8 No. 1, p. 101.

Bowen, J.T. and McCain, S.L. (2015), "Transitioning loyalty programs: a commentary on "the relationship between customer loyalty and customer satisfaction", International Journal of Contemporary Hospitality Management, Vol. 27 No. 3, pp. 415-430.

Budianto, A. (2019), "Customer loyalty: quality of service”, Journal of Management Review, Vol. 3 No. 1, pp. 299-305.

Caruana, A., Money, A.H. and Berthon, P.R. (2000), "Service quality and satisfaction-the moderating role of value", European Journal of Marketing, Vol. 34 Nos 11/12, pp. 1338-1353.

Caruana, A., Vella, J., Konietzny, J. and Chircop, S. (2018), "Corporate greed: its effect on customer satisfaction, corporate social responsibility and corporate reputation among bank customers", Journal of Financial Services Marketing, Vol. 23 Nos 3/4, pp. 226-233.

Cha, J. and Borchgrevink, C.P. (2018), "Customers' perceptions in value and food safety on customer satisfaction and loyalty in restaurant environments: moderating roles of gender and restaurant types", Journal of Quality Assurance in Hospitality and Tourism, Vol. 20 No. 2, pp. 143-161.

Chang, H.H. and Wong, K.H. (2018), "Consumer psychological reactance to coalition loyalty program: price-consciousness as a moderator”, Service Business, Vol. 12 No. 2, pp. 379-402.

Chen, I.J., Gupta, A. and Rom, W. (1994), "A study of price and quality in service operations", International Journal of Service Industry Management, Vol. 5 No. 2, pp. 23-33.

Dahiyat, S.E., Akroush, M.N. and Abu-Lail, B.N. (2011), "An integrated model of perceived service quality and customer loyalty: an empirical examination of the mediation effects of customer satisfaction and customer trust", International Journal of Services and Operations Management, Vol. 9 No. 4, pp. 453-490.

Fornell, C. and Larcker, D.F. (1981), "Structural equation models with unobservable variables and measurement error: Algebra and statistics", Journal of Marketing Research, Vol. 18 No. 3, pp. 382-388.

Gefen, D. (2002), "Customer loyalty in e-commerce”, Journal of the Association for Information Systems, Vol. 3 No. 1, pp. $27-51$.

Hafeez, S. and Muhammad, B. (2012), "The impact of service quality, customer satisfaction and loyalty programs on customer's loyalty: evidence from banking sector of Pakistan", International Journal of Business and Social Science, Vol. 3 No. 16, pp. 200-209. 
Hair, J.F., Ringle, C.M. and Sarstedt, M. (2011), "PLS-SEM: Indeed a silver bullet”, Journal of Marketing Theory and Practice, Vol. 19 No. 2, pp. 139-152.

Hallowell, R. (1996), "The relationships of customer satisfaction, customer loyalty, and profitability: an empirical study", International Journal of Service Industry Management, Vol. 7 No. 4, pp. $27-42$.

Han, H. and Hyun, S.S. (2015), "Customer retention in the medical tourism industry: impact of quality, satisfaction, trust, and price reasonableness", Tourism Management, Vol. 46 No. 1, pp. $20-29$.

Hussain, A. and Routray, J.K. (2012), "Status and factors of food security in Pakistan", International Journal of Development Issues, Vol. 11 No. 2, pp. 164-185.

Hussain, R., Al Nasser, A. and Hussain, Y.K. (2015), "Service quality and customer satisfaction of a UAE-based airline: an empirical investigation", Journal of Air Transport Management, Vol. 42 No. 1, pp. 167-175.

Hutahayan, B. (2019), "Factors affecting the performance of Indonesian special food SMEs in entrepreneurial orientation in east java”, Asia Pacific Journal of Innovation and Entrepreneurship, Vol. 13 No. 2, pp. 231-246.

Ivkov, M., Blešić, I., Simat, K., Demirović, D. and Božić, S. (2018), "Innovations in the restaurant industry-an exploratory study", Economics of Agriculture, Vol. 63 No. 4, pp. 1169-1186.

Izogo, E.E. and Ogba, I.E. (2015), "Service quality, customer satisfaction and loyalty in automobile repair services sector", International Journal of Quality and Reliability Management, Vol. 32 No. 3, pp. 250-269.

Jiang, L., Jun, M. and Yang, Z. (2016), "Customer-perceived value and loyalty: how do key service quality dimensions matter in the context of B2C e-commerce?”, Service Business, Vol. 10 No. 2, pp. 301-317.

Kaura, V., Durga Prasad, C.S. and Sharma, S. (2015), "Service quality, service convenience, price and fairness, customer loyalty, and the mediating role of customer satisfaction", International Journal of Bank Marketing, Vol. 33 No. 4, pp. 404-422.

Keaveney, S.M. (1995), "Customer switching behavior in service industries: an exploratory study", Journal of Marketing, Vol. 59 No. 2, pp. 71-82.

Khan, M.M. and Fasih, M. (2014), "Impact of service quality on customer satisfaction and customer loyalty: evidence from banking sector", Pakistan Journal of Commerce and Social Sciences, Vol. 8 No. 2, pp. 331-354.

Khan, N.R. and Shaikh, U. (2011), "Impact of service quality on customer satisfaction: evidences from the restaurant industry in Pakistan", Management and Marketing, Vol. 9 No. 2, pp. 343-355.

Kiani, M.N., Mustafa, S.H. and Ahmad, M. (2019), "Does innovation capabilities affect the new service innovation success among Pakistani cellular companies?”, Asia Pacific Journal of Innovation and Entrepreneurship, Vol. 13 No. 1, pp. 2-16.

Kotler, P., Armstrong, G., Saunders, J. and Wong, V. (2000), "Fundamentals of marketing”, Moskow: Williams, Vol. 1 No. 1, pp. 89-107.

Li, C. and Asim, S. (2019), "Diffusion of innovation through individual and collective entrepreneurship", Asia Pacific Journal of Innovation and Entrepreneurship, Vol. 13 No. 1, pp. 89-107.

Matzler, K., Würtele, A. and Renzl, B. (2006), "Dimensions of price satisfaction: a study in the retail banking industry”, International Journal of Bank Marketing, Vol. 24 No. 4, pp. 216-231.

Nauman, S., Khan, A.M. and Ehsan, N. (2010), "Patterns of empowerment and leadership style in project environment”, International Journal of Project Management, Vol. 28 No. 7, pp. 638-649.

Oh, H. and Kim, K. (2017), "Customer satisfaction, service quality, and customer value: years 20002015”, International Journal of Contemporary Hospitality Management, Vol. 29 No. 1, pp. 2-29.

Ouedraogo, A. and Koffi, V. (2018), "Managing creativity and innovation in the cultural industries: evidence from three cultural organizations in Canada", Management Review: An International Journal, Vol. 13 No. 2, pp. 34-60. 
APJIE 14,3

Paek, J. and Lee, C.W. (2018), "The effect of education and training on service quality, customer satisfaction and loyalty in airline industry", Management Review: An International Journal, Vol. 13 No. 1, pp. 49-64.

Parasuraman, A., Zeithaml, V.A. and Berry, L.L. (1985), "A conceptual model of service quality and its implications for future research", Journal of Marketing, Vol. 49 No. 4, pp. 41-50.

Parasuraman, A., Zeithaml, V.A. and Berry, L.L. (1988), "Servqual”, Journal of Retailing, Vol. 64 No. 1, pp. $12-40$.

Ryu, K. and Han, H. (2010), "Influence of the quality of food, service, and physical environment on customer satisfaction and behavioral intention in quick-casual restaurants: moderating role of perceived price", Journal of Hospitality and Tourism Research, Vol. 34 No. 3, pp. 310-329.

Satti, Z.W., Babar, S.F. and Ahmad, H.M. (2017), "Mediating role of service quality between sensory marketing and customer loyalty in restaurant industry: a case of Pakistan", Journal of Managerial Sciences, Vol. 11 No. 3, pp. 297-314.

Satti, Z.W., Babar, S.F. and Ahmad, H.M. (2019), "Exploring mediating role of service quality in the association between sensory marketing and customer satisfaction", Total Quality Management and Business Excellence, Vol. 1 No. 1, pp. 1-18.

Schirmer, N., Ringle, C.M., Gudergan, S.P. and Feistel, M.S. (2018), "The link between customer satisfaction and loyalty: the moderating role of customer characteristics", Journal of Strategic Marketing, Vol. 26 No. 4, pp. 298-317.

Tandon, U., Kiran, R. and Sah, A.N. (2017), "Customer satisfaction as mediator between website service quality and repurchase intention: an emerging economy case”, Service Science, Vol. 9 No. 2, pp. 106-120.

Wolfinbarger, M. and Gilly, M.C. (2003), "e-TailQ: dimensionalizing, measuring and predicting retail quality”, Journal of Retailing, Vol. 79 No. 3, pp. 183-198.

Zeithaml, V.A. (1988), "Consumer perceptions of price, quality, and value: a means-end model and synthesis of evidence”, Journal of Marketing, Vol. 52 No. 3, pp. 2-22.

\section{Further reading}

Al Mamun, A., Fazal, S.A. and Muniady, R. (2019), "Entrepreneurial knowledge, skills, competencies and performance: a study of micro-enterprises in Kelantan, Malaysia”, Asia Pacific Journal of Innovation and Entrepreneurship, Vol. 13 No. 1, pp. 29-48.

\section{Corresponding author}

Zoya Wajid Satti can be contacted at: zoyawajid@yahoo.com

For instructions on how to order reprints of this article, please visit our website: 